\title{
A Brief Analysis of College Counselors to Improve the Realization of College Students' Legal Accomplishment
}

\author{
Yuchen Wang ${ }^{1,}$, Fang Fang ${ }^{1}$, Fuyu $\operatorname{Lei}^{1}$, Jun $\operatorname{Liu}^{1}$, Junzhe Chai ${ }^{1}$, Jingyi Liu ${ }^{1}$ \\ ${ }^{1}$ School of Mechanical Engineering and Automation, Wuhan University of Science and Technology, No.947. 430081, \\ China \\ "Corresponding author. Email: WangYuchen@wust.edu.cn
}

\begin{abstract}
College Counselors are not only the life mentors of college students seeking knowledge but also the intimate friends in terms of students' healthy growth. College students are the backbone of the future development of the country and society, and their legal quality directly affects the construction process of socialist material civilization, spiritual civilization and political civilization. This paper summarizes the present situation of legal consciousness of contemporary college students, at the same time, analyses the problems existing in the cultivation of legal consciousness in colleges and universities, then briefly describes how college Counselors can improve the practical path of legal literacy of college students.
\end{abstract}

Keywords: College Counselors, College Students, Legal Literacy, Realization Path

\section{Introduction}

Recently, with the continuous large-scale expansion of college enrollments in China, colleges and universities have developed rapidly. However, there is still an important problem in the management of college students, that is, their legal consciousness and legal concept are weak, and it is difficult for them to adapt to the development of society [5]. At present, most colleges and universities in our country pay more attention to specialized theoretical courses. Besides, the students' learning and self-discipline ability are different, which leads to the weak law awareness among some students. Many students prefer to be silent rather than fight for their rights when being violated, rather than fighting for their interests. What's worse, they even choose to use violence to achieve illegal purpose, leading to the frequent occurrence of crime phenomenon [6].

Legal consciousness is a form of social consciousness as well as an important guarantee for citizens to understand, respect, enforce and maintain socialist legal norms. Having certain legal consciousness can not only avoid the occurrence of illegal crimes, but also maintain the dignity of the law and establish the authority of the law. In the period of forming world outlook, life outlook and values, correct education and guidance are important for college students. As a significant part of the student management team, college counselors fight in the front line of ideological and political education of college students. Counselors play an indispensable role in raising college students' legal consciousness. Moreover, the process of cultivating students' legal consciousness itself also requires the selfimprovement of counselors' legal literacy, which requires counselors to find countermeasures to cultivate students' legal consciousness on the basis of fully understanding the characteristics of college students.

\section{Reasons for College Students' Lack of Legal Quality}

In order to systematically and comprehensively understand the legal awareness of mechanical students in colleges and universities, the questionnaire was designed from the significance of the course "Ideological and Moral Cultivation and Basic Law", whether the counselors are of great help, whether their legal awareness needs to be improved, and whether they are willing to continue to improve their legal awareness, etc. The questionnaire was designed. All undergraduate students in the School of Mechanical Automation of Wuhan University of Science and Technology were investigated, the sample size is 2356. A total of 510 questionnaires were sent from March 1 to May 1, 2020, including 503 valid questionnaires.

Table 1 Proportion of students participating in the survey

\begin{tabular}{cc}
\hline Assessment & Percentage \\
\hline Freshman & $53.2 \%$ \\
Sophomore & $26.2 \%$ \\
Junior & $14.7 \%$ \\
Senior & $5.9 \%$ \\
\hline
\end{tabular}

It could be seen that the students participating in the survey covered the whole four years, and the proportion of freshmen exceeded $50 \%$. The number of students from the lower grades to the upper grades shows a decreasing trend (Table 1). About $92 \%$ of students think that legal courses 
are very meaningful, $85 \%$ of students think that counselors have played an important role in improving their legal awareness, but only $76 \%$ of students think they have enough legal awareness (Figure 1).

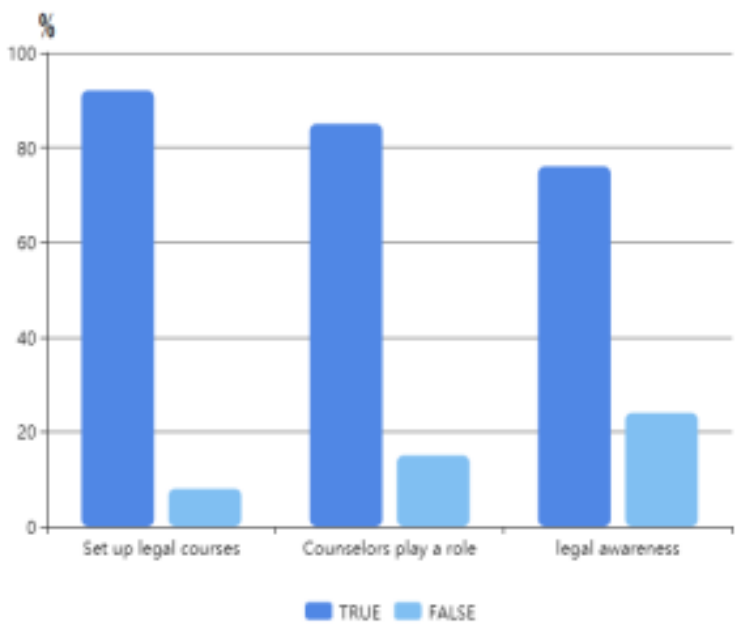

Figure 1 Questionnaire of students' legal awareness

Combining the results of the data from the questionnaire mentioned above, the following analysis can be made, the current situation of college students' lack of legal quality in China is caused not only by their own learning initiative, but also by the current college curriculum and the quality cultivation of college students.

\subsection{Problems existed in the cultivation of college students' legal quality}

At present, the course where undergraduates in our country can contact law is "Ideological and Moral Cultivation and Legal Basis". This textbook brings out China's constitutional system and the concept of rule by law in three chapters. After the completion of this course in the freshman year, except for some elective courses, ordinary college students won't have no further opportunity to learn relevant knowledge of the law. The cultivation of college students' legal quality requires a step by step process. It is difficult to improve the legal quality of college students effectively if the legal knowledge of college students is simply imparted through a course.

As mentioned above, the teaching of legal quality education for college students is completed against the teaching of ideological education courses, at the same time, those who are engaged in teaching are generally ideological and political class teacher most of whom have no legal education background or specialized legal training experience. Due to the lack of professional background, many experienced counselors are not accurate in legal and academic research in teaching, so it is difficult for them to adapt to the current requirements of legal quality training for college students.
The way of legal quality education for college students in our country is quite traditional, which is mainly taught by teachers, leading to students' relatively limited learning initiative. Thus, they cannot meet the requirements of legal quality education. To improve one college student's legal quality means to comprehensively improve his or her legal knowledge, legal awareness and legal ability. For the college students, although they do not need systematic law education like law undergraduates, they should be able to master certain knowledge, acquire the legal awareness that qualified citizens should have, and possess the law application ability.

\subsection{Problems exposed of counselors in the process of cultivating college students' legal quality}

The content of ideological education that the counselors imparts to college students mainly includes "World Views", Socialism Belief, Patriotism, Collectivism and Excellent Traditional Morality education. Every single matter has pros and cons, so as in cultivating college students' legal quality. Let's assume that in order to complete the tasks arranged by the department leaders, the counselors ignore whether they have "Ethical Justice" in nature. Such excessive ideological education based on "Obligation Standard" could breed college students' sense of legal external. The traditional view of benevolence and virtue can easily lead to the nihilistic sense of law. The old saying, he who excels in learning can be an official, has encouraged a sense of legal alienation. Also, the Confucianism tradition, morality given priority over penalty, has strengthened the tendency of instrumentalism in contemporary college student group. These negative influences have shaped the cognitive, emotional and behavioral disorders in the process of cultivating the legal consciousness of contemporary college students, as well as delayed the process of cultivating the legal consciousness of college students.

\subsection{Self-Reasons for College Students' Lack of Legal Quality}

The legal quality is mainly manifested in the law cognition, the requirements and attitude towards the current law, the evaluation, understanding and interpretation of law operation, the evaluation of the legality of human behavior, and the ability to observe and use the law [3]. Generally speaking, college students' understanding of the nomocracy manifests in three aspects, law-abiding consciousness, lawusing consciousness and law-protecting consciousness. It is the basic requirement for college students to obey the law and fulfill the obligations under the law. Most college students have a strong awareness in this respect. However, not only their awareness of using laws to protect the legal rights of the state is relatively weak, but also their awareness of resolving disputes through legal due process. Lawprotecting consciousness, also known as the concept of 
legal supremacy, upholds the dignity of the law, and the consciousness of fighting against all illegal acts are far from reaching the hearts of college students.

\section{The Importance of Improving College Students' Legal Literacy}

Although college students are excellent talents in today's society, the consequences are unimaginable once their will is not firm enough, their ideas cannot advance with the times, or social negative factors have an impact on their worldview values. At the same time, college students are in the middle of adolescence, sometimes leads to their inevitable irrational behavior. Impulsive behavior often leads to irreparable consequences. Lacking basic legal common sense and doing things simply based on subjective assumptions will have an adverse impact on others and society.

In today's world, science and technology are advancing with each passing day, and the knowledge economy is developing rapidly. The pace of economic globalization has accelerated significantly, and intellectual property rights have become a focus of international economic and corporate competition. In the development of professional fields of college students, whether they are engaged in theoretical research or production practice, the results of their intellectual labor are ultimately manifested as copyrights and intellectual property rights such as inventions, and designs. "On the one hand, the protection of intellectual property rights has promoted the development of science and technology. On the other hand, the rapid development of contemporary high-tech has made hightech intellectual achievements not involved in traditional intellectual property rights, such as integrated circuits, computer networks, multimedia program production, satellite communication, and bioengineering, appear constantly. Certainly, this has posed a new challenge to the traditional intellectual property rights protection and opened up a new field of intellectual property rights protection. It can be predicted that high and new technology will become the basis for the further development of intellectual property rights. Meanwhile, the scope of intellectual property rights protection will be continuously expanded with the development of high and new technology."

To solve the problem of defining the attribution of these intellectual property rights and how to use them legally so that they can both encourage innovation and promote social development. There is a set of relevant laws and regulations both at home and abroad. Only college students who are familiar with these relevant laws and regulations can have more sources and motivation for learning and creation, can better protect their legal rights, and can realize their own and national related industrial development strategies. Finally realize the value of one's life.

\section{How College Counselors Improve the Realization of College Students' Legal Literacy}

\subsection{The responsibilities of college counselors in the cultivation of college students' legal quality}

College counselors are the most basic teaching staff of college students. They maintain the most frequent and direct contact with college students. Therefore, as far as the legal quality of college students is concerned, counselors have important responsibilities. At the same time, the counselor also has a unique advantage because of the particularity of the job. Dealing with students who have different thoughts and different behaviors, counselors work with the aid of students' thoughts, words, deeds and results. Counselors work from the ideal to the trivial things of life, such as ideological education, mental health education, study style construction, party building, awards and assistance loans, employment guidance, daily affairs management and so on. All of these are the content of the work that the counselor needs to be involved in the entire college period of the students. In the process of direct contact with college students, the counselors not only act as the backbone of students' ideological and political education, but also serve as a guide for the healthy growth of college students in this period. It is precisely because of the special position and functional positioning of college counselors that they play an irreplaceable and important role in the cultivation of college students' legal quality.

\subsection{The way for college counselors to intervene in the realization of the training of college students' legal quality}

College students are the country's future and hope, and also the reserve pillar of social and economic development. College counselors should inculcate the concept of historical responsibility for college students. It is a systematic project to improve the legal quality of college students in an all-round way and it's a long way to go. There is a lot to do, and the situation to be faced is very complex. But counselors have their own unique advantages. Counselors can effectively realize the training of the legal quality of college students in the light of their own characteristics.

\subsubsection{Cultivating college students' legal concepts in daily management}

In the process of college students' education and management, the counselor usually exercises the rights and performs the obligation on behalf of the school. Therefore, 
the counselor should pay attention to the coordination of the administrative legal relationship and the civil legal relationship in the process of dealing with the daily affairs of college students.

\subsubsection{Urging college students to learn law courses well, college counselors are the guide of College Students}

It's one of the counselors' duties to urge the students to study and help them finish their studies. "Thought morals tutelage and legal foundation" is a basic method to learn legal knowledge. A counselor should help college students to understand the significance of learning this course, contemplate legal knowledge having been taught in class and legal issues having been focused by college students, also appropriately bring these contents into theme class meeting. Therefore, to further improve the enthusiasm and initiative of college students to study law, counselors should encourage students who are not major in law to take relevant general courses, so that they can have a more detailed and in-depth understanding of China's legal system as far as possible in college period.

\subsubsection{Striving to improve the Counselor's own legal quality and ability}

In the process of practical work and intervening in the legal quality education of College Students, college counselors should strengthen their own cultivation, and learn to summarize and accumulate the practical experience when they learn the legal knowledge. Specifically, the improvement of legal quality and ability of counselors mainly includes two parts, strengthening the study and practice of law.

\section{CONCLUSION}

Due to the characteristics of college counselors' own work, college counselors have their own unique advantages in the cultivation of the legal quality of college students, especially illegal majors. As long as the majority of college counselors are able to use their brains, make positive attempts and be good at summary, they will have great potential in the cultivation of the legal quality of college students. In addition, college counselors should pay attention to strengthening their own legal knowledge learning, legal awareness training and practical application while intervening in the cultivation of college students' legal quality. Only by doing the above points at the same time can college counselors calmly and effectively train the legal quality of college students.

\section{REFERENCES}

[1] Shouquan Chen. (2019) Discussion on ways to strengthen the legal quality education of college students. law System and Society, 32: 199-200.

[2] Feng Xue. (2019) Research on the cultivation of college students' legal consciousness and reform of legal teaching. Think tank Times, 21: 97-98.

[3] Cuifang Yan. (2019) The Dilemma and Path Exploration of Law Education for College Students in Higher Vocational Colleges. Huai Journal of Southern Vocational and Technical College, 19 (04): 110-111.

[4] Jinghui Wang. (2017) Based on ideological and political education on the cultivation and improvement of college students' legal consciousness. Curriculum Education Research, 35: 90-91.

[5] Lei Wang. (2017) The status quo of college students' legal awareness and promotion strategies. Legal Expo, 3: 265.

[6] Yingjie Deng. (2016) Under the background of ruling the country by law, the realistic dilemma and path construction of college students' education of law. East China University of Political Science and Law. 